\title{
Comparative study of hemodynamic responses during laryngoscopy and endotracheal intubation with Dexmedetomidine and Esmolol
}

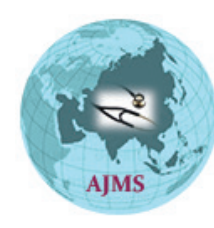

\author{
Vigneshwaran Chandramohan ${ }^{1}$, Ramya Natarajan ${ }^{2}$, Vishwanath R Hiremath ${ }^{3}$ \\ ${ }^{1}$ Assistant Professor, ${ }^{2}$ Associate Professor, ${ }^{3}$ Professor, Department of Anaesthesia, Sri ManakulaVinayagar Medical \\ College and Hospital, Pondicherry, India
}

Background: Many drugs used to reduce the hemodynamic stress response during laryngoscopy and endotracheal intubation. The quest for ideal drugs and their dosage without major side effects is still pursued. Dexmedetomidine, an alpha-2 agonist, is emerging as a promising drug to counteract the catecholamine release. Aims and Objectives: This study is done to compare the effect of lower doses dexmedetomidine and esmolol in control of hemodynamic response and stability in cases undergoing laryngoscopy and endotracheal intubation during general anesthesia.Setting and Design: This was a prospective, randomized double-blinded comparative study.Materials and Methods: After approved by the Institute Ethics Committee, consent obtained from 60 patients $(n=60)$ belonging to ASA I or II. Patients were equally divided into twogroups ( $D$ and $E)$. Group $D$ patients $(n=30)$ were infused with intravenous dexmedetomidine at $0.75 \mathrm{mcg} / \mathrm{kg}$ diluted in $20 \mathrm{ml}$ with normal saline 10 min before induction. Group E patients $(n=30)$ were infused with intravenous esmolol $0.75 \mathrm{mg} / \mathrm{kg}$ diluted in $20 \mathrm{ml}$ of normal saline $2 \mathrm{~min}$ before intubation. After administration of drugs, SBP, DBP, MAP, $\mathrm{HR}$, and $\mathrm{SpO}_{2}$ were recorded, immediately after induction, after intubation at $1 \mathrm{~min}, 3 \mathrm{~min}, 5 \mathrm{~min}$, and $10 \mathrm{~min}$, respectively. Results: Data wereentered into Microsoft Excel datasheet and wereanalyzed using SPSS 22 version software. In the study, there was a significant decrease in SBP, DBP, MAP, and HR from administration till 10 min after intubation inGroup D compared to Group E. No severe hypotension or bradycardia was seen in any of the patients in either group, took part in our study.Conclusion: This study concludes low dose of dexmedetomidine $(0.75 \mathrm{mcg} / \mathrm{kg})$ was superior to low dose of esmolol $(0.75 \mathrm{mg} / \mathrm{kg})$ in maintaining of hemodynamic stability in response to laryngoscopy and tracheal intubation without any significant adverse effects even though both drugs were comparable in suppressing pressor response.
Access this article online

Website:

http://nepjol.info/index.php/AJMS

DOI: 10.3126/ajms.v13i3.40791

E-ISSN: 2091-0576

P-ISSN: 2467-9100

Copyright (c) 2022 Asian Journal of Medical Sciences

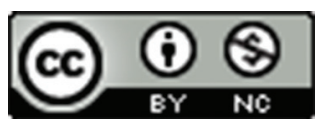

This work is licensed under a Creative Commons Attribution-NonCommercial 4.0 International License.

Key words: Dexmedetomidine; Esmolol; Hemodynamics; Laryngoscopy

\section{INTRODUCTION}

Endotracheal intubation and laryngoscopy area core integral skill of anesthetic management in general anesthesia and critical care of the patient as first described by Rowbotham and Magill in 1921. ${ }^{1}$ Laryngoscopy with further negotiation of endotracheal tube inside trachea stimulates the sympathoadrenal receptors releasing catecholamines in blood that transiently storms a pressor response characterized by the elevation of systolic blood pressure (SBP), diastolic blood pressure(DBP), and heart rate (HR). The response to laryngoscopy and tracheal intubation is a somatovisceral kind of reflex. It depends mainly on two factors such as duration and force of the procedureclinically. In pediatrics, such a response may lead to reflex vagal inhibition of the heart manifesting as bradycardia.

This pressor response manifests within $5 \mathrm{~s}$ and further elevates while endotracheal tube enters inside trachea. 
Average rise of SBP is $25-50 \mathrm{mmHg},{ }^{2-6}$ following a plateau at or above this peak pressure is sustained for 1-2 min. It takes about 5-10 min for the pressures to return to pre laryngoscopic value. ${ }^{7,8}$ Such disturbances in hemodynamics are well withstood by normal individuals or the American Society of Anesthesiologist (ASA) 1 patients. Even, controlled hypertensives patients are more prone to elevations in pressures. Patients with limited cardiovascular reserve, coronary artery disease, cardiac dysrhythmia, cardiomyopathy, congestive heart failure, hypertension, limited intracranial compliance, and geriatric population may land to life-threatening complications such asmyocardial ischemia, acute cardiac failure, and cerebrovascular hemorrhage. ${ }^{9,10}$ Hemodynamic response to laryngoscopy and intubation in anesthetized persons wasfirst reported by Donegan et $\mathrm{al}^{11}$ Since then, research works have been carried out to attenuate or prevent these responses and various measures such as shortening duration of laryngoscopy, smooth intubation, airway anesthesia by blocking superior laryngeal nerve, recurrent laryngeal nerve and topical lignocaine, beta-blockers, calcium channel blockers, and intravenous lignocaine. ${ }^{12-15}$

Various strategies with drugs and non-pharmacological techniques have been carried out for obtunding the stress response to laryngoscopy and intubation, including opioids, barbiturates, benzodiazepines, beta-blockers, calcium channel blockers, and vasodilators. ${ }^{16-20}$

Esmolol is an ultra-short-acting, beta-adrenergic receptor blockerwhich has been proven efficacious clinically to provide hemodynamic control during laryngoscopy and intubation without severe sideeffects. ${ }^{16,17}$

Newer alpha-2 agonists such asclonidine and dexmedetomidine have been used currently for obtunding sympathoadrenal stimulation by tracheal intubation and surgery. ${ }^{18}$ Dexmedetomidine blunts hemodynamic response and provides conducive hemodynamics during the placement of endotracheal tube..$^{21,22}$

\section{Aims and objectives}

The current study was done to compare the effect of lower doses of dexmedetomidine and esmolol for control of hemodynamic response and stability among cases undergoing laryngoscopy and endotracheal intubation during general anesthesia.

\section{MATERIALS AND METHODS}

The current study was prospective, randomized controlled double-blinded study conducted after the approval of the Institutional Ethics Committee andregistration in
Clinical Trials Registry India with registration number CTRI/2019/05/019172.

\section{Sample size}

Sample size was calculated using OpenEpi software, version 3.0. by comparing with the previous studies ${ }^{14}$ mean and standard deviation of mean arterial pressure (MAP) at various time intervals as $77.4 \pm 10.1,86.1 \pm 10.1$ for dexmedetomidine and esmolol, respectively, with probability of type 1 error $(\alpha<0.05), 80 \%$ power, $95 \%$ confidence interval, and non-response rate of $10 \%$. Sample size of 60 was calculated with 30 in each group.

\section{Inclusion criteria}

The following criteria were included in the study:

1. Age group 18-60 years

2. Both genders

3. ASA Grade I or II

4. Modified Mallampati Grade 0/I/II.

\section{Exclusion criteria}

The following criteria were excluded from the study:

1. Patients refusal

2. Pregnancy

3. Emergency surgeries

4. Patients with anticipated difficult airway

5. $\mathrm{BMI}>30$

6. Modified Mallampati Grade III/IV

7. Patients with ischemic heart disease, hypertension, and diabetes mellitus.

8. H/o chronic respiratory, hepatic, renal diseases, and on antipsychiatric medications.

9. H/o drug allergy

10. Laryngoscopy time $>20 \mathrm{~s}$.

\section{Technique of anesthesia}

All the study subjects underwent pre-anesthetic checkup and written informed consent was obtained. On the day of surgery, patients were shifted to the operating room and then standard monitors were connected and baseline parameters such as $\mathrm{HR}, \mathrm{SBP}, \mathrm{DBP}$, and $\mathrm{SpO}_{2}$ were recorded. Patients were pre-medicated with inj.glycopyrrolate $0.004 \mathrm{mg} / \mathrm{kg}$ iv, inj. midazolam $0.03 \mathrm{mg} / \mathrm{kg}$ iv, and fentanyl $2 \mathrm{mcg} / \mathrm{kg}$ iv.

Dexmedetomidinegroup (Group D) patients received single bolus infusion of dexmedetomidine $0.75 \mathrm{mcg} /$ $\mathrm{kg}$ diluted in $20 \mathrm{ml} 0.9 \%$ normal saline over $10 \mathrm{~min}$. Esmololgroup (Group E) patients received single IV bolus of esmolol $0.75 \mathrm{mg} / \mathrm{kg}$ diluted in $20 \mathrm{ml} 0.9 \%$ normal saline over $10 \mathrm{~min}$.

After the study, drug administration patients were preoxygenated and induced with inj. propofol $2 \mathrm{mg} / \mathrm{kg}$ iv. After confirming the feasibility to ventilation, inj.vecuronium 
$0.1 \mathrm{mg} \mathrm{kg}^{-1}$ supplemented to facilitate laryngoscopy and tracheal intubation. After $3 \mathrm{~min}$ of giving vecuronium, using laryngoscope with Macintosh blade, intubation of the trachea was done with well lubricated appropriately sized cuffed endotracheal tube. Laryngoscopy and intubation time werekept minimum $<20 \mathrm{~s}$. The tube was fixed after confirmation of bilateral air entry. Anesthesia was maintained with $\mathrm{N}_{2} \mathrm{O} 66 \%, \mathrm{O}_{2} 33 \%$, isoflurane 1-1.6\%, in controlled ventilation. HR, SBP, DBP, mean arterial pressure (MAP), electrocardiogram, and $\mathrm{SpO}$, were recorded immediately on arrival before administration of drugs, after administration of drugs, induction of anesthesia, $1 \mathrm{~min}, 3 \mathrm{~min}, 5 \mathrm{~min}$, and 10 min after laryngoscopy and intubation, respectively. No surgical stimulus was allowed till $10 \mathrm{~min}$ post-intubation. After the completion of surgery, with return of respiratory efforts, residual neuromuscular blockade was reversed with inj. neostigmine $0.05 \mathrm{mg} \mathrm{kg}^{-1}$ and inj. glycopyrrolate $0.01 \mathrm{mg} \mathrm{kg}^{-1}$. Patients were extubated after recovery from neuromuscular block and were shifted to post-operative ward.

\section{RESULTS}

Baseline demographic and clinical characteristics among the two groupsareshown in Table 1.

The baseline demographic and the clinical characteristics among the two groups areshown in Table 1. Majority of the patients were in the age group of 21-40 years and were belonging to ASA Class I. There was equal representation of both genders. The distribution of all the characteristics wassimilar in both the drug groups $(\mathrm{P}>0.05)$.

SBP was significantly reduced after administration of the dexmedetomidine to 5 min post-intubation $(\mathrm{P}<0.001)$, as shown in Table 2.
Similarly, DBP was found to be significantly reduced after administration of dexmedetomidine to $10 \mathrm{~min}$ postintubation $(\mathrm{P}<0.001)$ between two groups except at $1 \mathrm{~min}$ of intubation, as shown in Table 3.

MAP was significantly reduced after administration till 10 min post-intubation $(\mathrm{p}<0.001)$ in the dexmedetomidine group, as shown in Table 4.

HR was found to be significantly decreased in Group D 1 min after intubation to 5 min post-intubation with high statistical significance value $(\mathrm{P}<0.001)$ between two groups, as shown in Table 5.

The SBP, DBP, MAP, and HR of both dexmedetomidine and esmolol areshown in Figures 1-4, respectively. Figures indicate better maintenance of suppressed pressor response by dexmedetomidine from time of induction to $10 \mathrm{~min}$ post-induction. This study concluded that Group D dexmedetomidine at $0.75 \mathrm{mcg} \mathrm{kg}^{-1}$ was superior compared to Group E (esmolol $0.75 \mathrm{mcg} \mathrm{kg}^{-1}$ ) at $1 \mathrm{~min}$ and $10 \mathrm{~min}$ post-intubation in attenuation of hemodynamic response.

\section{DISCUSSION}

Laryngoscopy and endotracheal intubation areperformed after induction with good will, it is not devoid of complications. On stimulation, laryngoscopy within $5 \mathrm{~s}$ activates sympathoadrenal reflex and propagates stress responses that suddenly surge catecholamines resulting in tachycardia and hypertension which can be withstood by normal patients. Such changes may unpleasantly result in myocardial ischemia, arrhythmias, raised intracranial pressure, raised intraocular pressure, laryngospasm, and bronchospasm in patients of limited cardiac reserve due to the disturbance of demand versus supply (oxygen)

\section{Table 1: Baseline demographic and clinical characteristics among the two groups $(n=60)$}

\begin{tabular}{|c|c|c|c|}
\hline & Group D & Group E & $P$ value \\
\hline \multicolumn{4}{|l|}{ Age group, $\mathrm{n}(\%)$} \\
\hline$\leq 20$ years & $3(10 \%)$ & $3(10 \%)$ & $0.526^{*}$ \\
\hline $21-30$ years & $10(33.3 \%)$ & $7(23.3 \%)$ & \\
\hline $31-40$ years & $10(33.3 \%)$ & $14(46.7 \%)$ & \\
\hline $41-50$ years & $6(20 \%)$ & $3(10 \%)$ & \\
\hline$>50$ years & $1(3.3 \%)$ & $3(10 \%)$ & \\
\hline \multicolumn{4}{|l|}{ Gender, n (\%) } \\
\hline Female & $14(46.7 \%)$ & $16(53.3 \%)$ & $0.606^{*}$ \\
\hline Male & $16(53.3 \%)$ & $14(46.7 \%)$ & \\
\hline \multicolumn{4}{|c|}{ American Society of Anesthesiologist, $\mathrm{n}(\%)$} \\
\hline I & $24(80 \%)$ & $20(66.7 \%)$ & $0.245^{*}$ \\
\hline II & $6(20 \%)$ & $10(33.3 \%)$ & \\
\hline Systolic blood pressure, mean ( $\pm S D)$ & $125.3( \pm 8.1)$ & $122.6( \pm 7.8)$ & $0.199^{\wedge}$ \\
\hline Diastolic blood pressure, mean $( \pm S D)$ & $77.9( \pm 6.4)$ & $78.1( \pm 6.4)$ & $0.904^{\wedge}$ \\
\hline Mean arterial pressure, mean $( \pm S D)$ & $93.7( \pm 5.6)$ & $93.0( \pm 4.8)$ & $0.578^{\wedge}$ \\
\hline Heart rate, mean $( \pm S D)$ & $80.0( \pm 7.0)$ & $77.3( \pm 5.6)$ & $0.111^{\wedge}$ \\
\hline
\end{tabular}


Table 2: Mean SBP comparison among two groups at various intervals of follow-up

\begin{tabular}{|c|c|c|c|c|c|c|c|}
\hline \multirow[t]{3}{*}{ SBP } & \multicolumn{6}{|c|}{ Group } & \multirow[t]{3}{*}{$P$ value between groups } \\
\hline & \multicolumn{3}{|c|}{ Group D } & \multicolumn{3}{|c|}{ Group E } & \\
\hline & Mean & $\pm S D$ & $\begin{array}{l}\text { P value within } \\
\text { group }\end{array}$ & Mean & $\pm S D$ & $\begin{array}{c}P \text { value } \\
\text { within group }\end{array}$ & \\
\hline Baseline & 125.27 & 8.06 & - & 122.60 & 7.83 & - & 0.199 \\
\hline After admin & 113.87 & 7.37 & $<0.001^{*}$ & 121.53 & 7.84 & $0.002^{*}$ & $<0.001^{*}$ \\
\hline After induction & 102.07 & 6.36 & $<0.001^{*}$ & 110.73 & 7.02 & $<0.001^{*}$ & $<0.001^{*}$ \\
\hline $1 \min$ & 102.33 & 5.80 & $<0.001^{*}$ & 117.60 & 6.86 & $<0.001^{*}$ & $<0.001^{*}$ \\
\hline $3 \min$ & 105.80 & 5.18 & $<0.001^{*}$ & 121.00 & 6.72 & $0.036^{*}$ & $<0.001^{*}$ \\
\hline $5 \mathrm{~min}$ & 111.67 & 5.61 & $<0.001^{*}$ & 119.07 & 7.52 & $<0.001^{*}$ & $<0.001^{*}$ \\
\hline $10 \mathrm{~min}$ & 118.00 & 5.63 & $<0.001^{*}$ & 119.60 & 6.90 & $<0.001^{*}$ & 0.329 \\
\hline
\end{tabular}

SBP: Systolic blood pressure

\begin{tabular}{|c|c|c|c|c|c|c|c|}
\hline \multirow[t]{3}{*}{ DBP } & \multicolumn{6}{|c|}{ Group } & \multirow[t]{3}{*}{$P$ value between groups } \\
\hline & \multicolumn{3}{|c|}{ Group D } & \multicolumn{3}{|c|}{ Group E } & \\
\hline & Mean & $\pm S D$ & $P$ value within group & Mean & $\pm S D$ & $P$ value within group & \\
\hline Baseline & 77.93 & 6.44 & - & 78.13 & 6.41 & - & 0.904 \\
\hline After admin & 68.93 & 6.16 & $<0.001^{*}$ & 77.53 & 5.89 & 0.240 & $<0.001^{*}$ \\
\hline After induction & 61.00 & 6.07 & $<0.001^{*}$ & 72.87 & 5.53 & $<0.001^{*}$ & $<0.001^{*}$ \\
\hline $1 \mathrm{~min}$ & 60.67 & 5.76 & $<0.001^{*}$ & 61.33 & 4.85 & $<0.001^{*}$ & 0.630 \\
\hline $3 \mathrm{~min}$ & 61.33 & 5.54 & $<0.001^{*}$ & 66.60 & 5.01 & $<0.001^{*}$ & $<0.001^{*}$ \\
\hline $5 \mathrm{~min}$ & 63.87 & 5.48 & $<0.001^{*}$ & 71.60 & 4.88 & $<0.001^{*}$ & $<0.001^{\star}$ \\
\hline $10 \mathrm{~min}$ & 66.40 & 6.04 & $<0.001^{*}$ & 75.53 & 5.14 & $0.002^{*}$ & $<0.001^{*}$ \\
\hline
\end{tabular}

DBP: Diastolic blood pressure

Table 4: Mean MAP comparison among two groups at various intervals of follow-up

\begin{tabular}{|c|c|c|c|c|c|c|c|}
\hline \multirow[t]{3}{*}{ MAP } & \multicolumn{6}{|c|}{ Group } & \multirow[t]{3}{*}{$P$ value between groups } \\
\hline & \multicolumn{3}{|c|}{ Group D } & \multicolumn{3}{|c|}{ Group E } & \\
\hline & Mean & $\pm S D$ & $P$ value within group & Mean & $\pm S D$ & $P$ value within group & \\
\hline Baseline & 93.71 & 5.64 & - & 92.96 & 4.79 & - & 0.578 \\
\hline After admin & 83.91 & 5.10 & $<0.001^{*}$ & 92.20 & 4.82 & $0.049^{*}$ & $<0.001^{*}$ \\
\hline After induction & 74.69 & 4.90 & $<0.001^{*}$ & 85.49 & 4.89 & $<0.001^{*}$ & $<0.001^{*}$ \\
\hline $1 \mathrm{~min}$ & 74.56 & 4.59 & $<0.001^{*}$ & 80.09 & 4.42 & $<0.001^{*}$ & $<0.001^{*}$ \\
\hline $3 \min$ & 76.16 & 4.26 & $<0.001^{*}$ & 84.73 & 4.62 & $<0.001^{*}$ & $<0.001^{*}$ \\
\hline $5 \min$ & 79.80 & 4.34 & $<0.001^{*}$ & 87.42 & 4.60 & $<0.001^{*}$ & $<0.001^{*}$ \\
\hline $10 \mathrm{~min}$ & 83.60 & 4.69 & $<0.001^{*}$ & 90.22 & 4.59 & $<0.001^{*}$ & $<0.001^{*}$ \\
\hline
\end{tabular}

MAP: Mean arterial pressure

\begin{tabular}{|c|c|c|c|c|c|c|c|}
\hline \multirow[t]{3}{*}{ HR } & \multicolumn{6}{|c|}{ Group } & \multirow{3}{*}{$\begin{array}{c}P \text { value between } \\
\text { groups }\end{array}$} \\
\hline & \multicolumn{3}{|c|}{ Group D } & \multicolumn{3}{|c|}{ Group E } & \\
\hline & Mean & $\pm S D$ & $\begin{array}{c}P \text { value } \\
\text { within group }\end{array}$ & Mean & $\pm S D$ & $\begin{array}{c}P \text { value } \\
\text { within group }\end{array}$ & \\
\hline Baseline & 80.00 & 7.05 & - & 77.33 & 5.62 & - & 0.110 \\
\hline After admin & 75.60 & 6.73 & $<0.001^{*}$ & 75.47 & 5.82 & $<0.001^{*}$ & 0.935 \\
\hline After induction & 69.33 & 5.79 & $<0.001^{\star}$ & 71.27 & 4.25 & $<0.001^{\star}$ & 0.146 \\
\hline $1 \mathrm{~min}$ & 66.13 & 4.42 & $<0.001^{*}$ & 81.47 & 5.38 & $<0.001^{*}$ & $<0.001^{*}$ \\
\hline $3 \mathrm{~min}$ & 68.73 & 4.83 & $<0.001^{*}$ & 85.00 & 5.25 & $<0.001^{*}$ & $<0.001^{*}$ \\
\hline $5 \mathrm{~min}$ & 65.27 & 4.15 & $<0.001^{*}$ & 70.33 & 3.79 & $<0.001^{*}$ & $<0.001^{*}$ \\
\hline $10 \mathrm{~min}$ & 69.27 & 3.13 & $<0.001^{\star}$ & 68.47 & 3.63 & $<0.001^{\star}$ & 0.364 \\
\hline
\end{tabular}

HR: Heart rate 


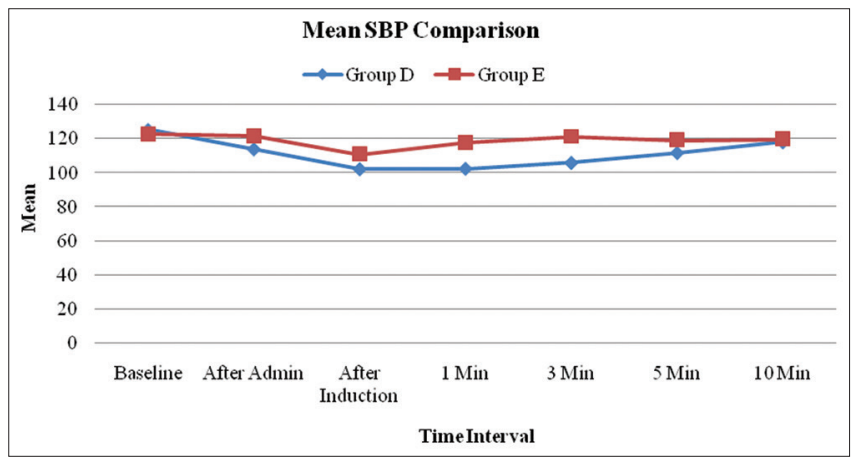

Figure 1: Line diagram showing mean systolic blood pressure comparison among two groups

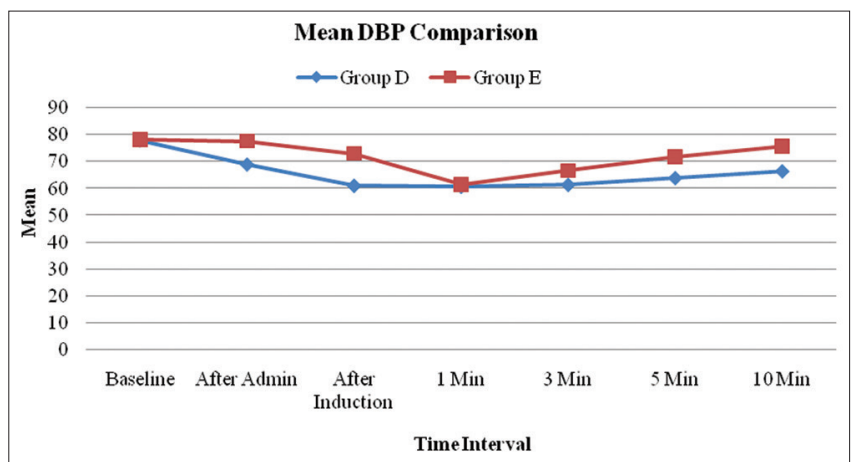

Figure 2: Line diagram showing mean diastolic blood pressure comparison among two groups

mismatch. The magnitude of response further escalates, peaks around 1-2 $\mathrm{min}$, and returns to pre-laryngoscopy level by $5-10 \mathrm{~min}$.

Recently, many studies are being carried out with newer $\alpha 2$ agonists such asdexmedetomidine and beta-blockers like esmolol at different dosage in attenuation of hemodynamic response.

Dexmedetomidine is a highly selective alpha-2 agonist having clinically favorable prospects such assedation with very easy arousal, sympatholysis, neuroprotection, analgesia, and anesthetic sparing effect with wide safety margin. In relation to the attenuation of hemodynamic stress response, dexmedetomidine decreased central sympathetic outflow, reducing serum epinephrine, and norepinephrine levels proportional to the dose. Therefore, dexmedetomidine causes dose-dependent reduction in arterial blood pressure and HR. At lesser dose, $0.25-0.5 \mathrm{mcg} \mathrm{kg}^{-1}$ dexmedetomidine only decreases blood pressure while at higher dose $1-2 \mathrm{mcg}$ $\mathrm{kg}^{-1}$, there was transient raise in blood pressure followed by hypotension and bradycardia. Hence, in our study, we selected dexmedetomidine $0.75 \mathrm{mcg} \mathrm{kg}^{-1}$.

Esmolol, a Class II antiarrhythmic agent, is a highly selective beta-1 receptor blocker with favorable properties such ascontrolling tachyarrythmias, myocardial oxygen

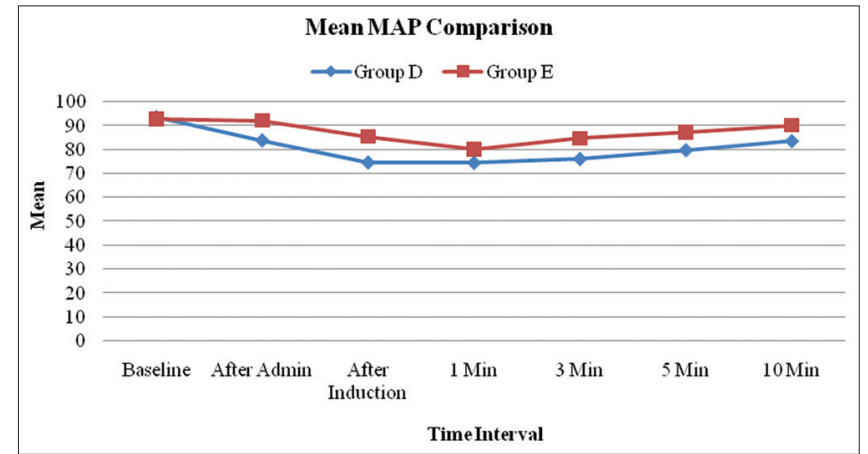

Figure 3: Line diagram for mean arterial pressure comparison among two groups

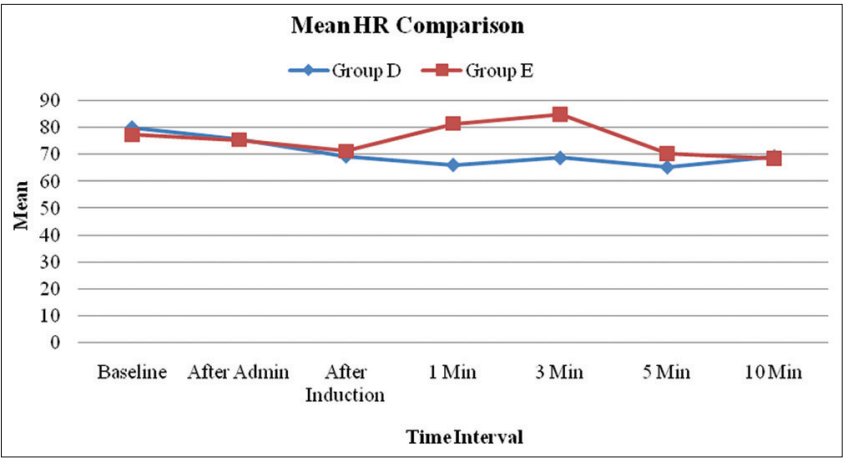

Figure 4: Line diagram for mean heart rate comparison among two groups

demand, coronary perfusion, restriction of infarct size, and improved rate pressure product. Esmolol inhibits the action of catecholamines on beta-receptors, thereby preventing the cardiovascular response due to laryngoscopy and endotracheal intubation. In the study by Miller et al., injection esmolol $1.5 \mathrm{mg} \mathrm{k}^{\mathrm{g}-1}$ and $3 \mathrm{mg} \mathrm{k}^{\mathrm{g}-1}$ were used and they observed adverse effects like hypotension while using higher dose of esmolol during induction and found optimal results with lesser dose. 23 This was basis for using smaller dose of $0.75 \mathrm{mg} \mathrm{kg}^{-1}$ in this study.

Anish Sharma compared clonidine $\left(3 \mathrm{mcg} \mathrm{k}^{\mathrm{g}}{ }^{-} 1\right)$ and dexmedetomidine $\left(1 \mathrm{mcg} \mathrm{k}^{\mathrm{g}-} 1\right)$ in his study and observed that dexmedetomidine at $1 \mathrm{mcg} \mathrm{k}^{g-} 1$ was more efficacious in attenuating the pressor response and also found that patients among clonidine group developed profound hypotension ${ }^{2} 4$ In a study by Fernandez-Galinski et al., comparing effects of alfentanyl $\left(3 \mathrm{mcg} \mathrm{kg}{ }^{-1}\right)$, esmolol $\left(1 \mathrm{mg} \mathrm{kg}^{-1}\right)$, and clonidine $\left(3 \mathrm{mcg} \mathrm{kg}{ }^{-1}\right)$ in attenuating cardiovascular response to endotracheal intubation, esmolol at $1 \mathrm{mg} \mathrm{kg}^{-1}$ gave conducive hemodynamics. ${ }^{25}$ Hence, based on the above studies, this study was carried out with dexmedetomidine and esmolol.

Dexmedetomidine $0.75 \mathrm{mcg} \mathrm{kg}^{-1}$ and esmolol $0.75 \mathrm{mg} \mathrm{kg}^{-1}$ were compared in the present study in attenuating hemodynamic response to laryngoscopy and 
endotracheal intubation as a single dose, administered intravenously. The SBP, DBP, MAPs, and HR were inferred to be decreased with high statistical significance from administration of both study drugs till 10 min postintubation. On core analysis of the study, it was revealed that Group D had complete attenuation of hemodynamic response to tracheal intubation compared to Group E. The above findings concluded that dexmedetomidine obtunds pressor response effectively following laryngoscopy and intubation.

Srivastavaet al., compared(Group C) $20 \mathrm{ml} \mathrm{0.9 \%} \mathrm{normal}$ saline, dexmedetomidine (Group D) $1 \mathrm{mcg} \mathrm{kg}^{-1}$, and group esmolol (Group E) $1.5 \mathrm{mg} \mathrm{kg}^{-1}$. Their study concluded that dexmedetomidine $1 \mathrm{mcg} \mathrm{kg}^{-1}$ was more efficacious than esmolol 1.5 $\mathrm{mg} \mathrm{kg}^{-1}$ for blunting hemodynamic stress response. ${ }^{26}$ Reddy et al., conducted a study to evaluate the effect of intravenous dexmedetomidine $\left(1 \mathrm{mcg} \mathrm{kg}^{-1}\right)$ infusion, esmolol $\left(2 \mathrm{mg} \mathrm{kg}^{-1}\right)$ intravenous infusions, and placebo on attenuation of pressor response to laryngoscopy and tracheal intubation. The study concluded that dexmedetomidine $1.0 \mathrm{mcg} \mathrm{kg}^{-1}$ proved to be dominant when compared to esmolol $2 \mathrm{mg} \mathrm{kg}^{-1}$ in providing a consistent and reliable blunting of sympathoadrenal response. ${ }^{27}$ The results of the above studies are in corroboration with the results of the present study.

However, in contrary to our study results, Gogus et al., concluded in their study that esmolol at $2 \mathrm{mg} \mathrm{kg}^{-1}$ was more competent in maintaining stable hemodynamics compared to dexmedetomidine at $1 \mathrm{mcg} \mathrm{kg}^{-1}$ during laryngoscopy and endotracheal intubation. ${ }^{28}$

In the present study, dexmedetomidine was administered slowly as an infusion over $10 \mathrm{~min}$ at dose of $0.75 \mathrm{mcg}$ $\mathrm{kg}^{-1}$ and no patient in this study developed severe bradycardia, hypotension, post-operative sedation, fall in $\mathrm{SpO}_{2}$, or needed oxygen supplementation.

There are limited studies that analyzed esmolol at dosage of $0.75 \mathrm{mg} \mathrm{kg}^{-1}$ infused 2 min before intubation on pressor response. Therefore, this study has tried to fill the gap in literature and established the potential benefit of esmolol at $0.75 \mathrm{mg} \mathrm{kg}^{-1}$ on attenuation of hemodynamic response. From time of administration till $10 \mathrm{~min}$ postintubation, there is a high statistical significant attenuation of hemodynamic response with no serious side effects or adverse outcomes in any participant. Hence, this study also analyzed the minimal effective dose for attenuation of intubation response among both the study drugs.

However, this study could not infer on the performance of both drugs in attenuating hemodynamic response to extubation, post-operative extubation standards with extubation scale, post-operative sedation, and postoperative analgesic requirements which extend the scope for future research.

\section{Limitations of the study}

The present study didn't have any Control group for comparing the characterisitics. Plasma catecholamine, cortisol, insulin levels were not analyzed which could have been more informative and as well as confirmative of stress response due to cost factor and non-availability of resources. Assessment of post-operative requirement of analgesics was not done as it was not part of the present study.

\section{CONCLUSION}

This study concludes that both dexmedetomidine $\left(0.75 \mathrm{mcg} \mathrm{kg}^{-1}\right)$ and esmolol $\left(0.75 \mathrm{mg} \mathrm{kg}^{-1}\right)$ have statistically significant attenuation of hemodynamic stress response to laryngoscopy and tracheal intubation without any adverse effects. Although, the study drugs have favorable reduction in hemodynamic response, dexmedetomidine has better maintenance of hemodynamicsfollowing intubation.

\section{ACKNOWLEDGMENT}

The authors would like to acknowledge the assistance from the Department of Anaesthesia and the management of Sri Manakula Vinayaga Medical College and Hospital for providing the assistance required for the conduct of the study. The authors would also like to thank all the patients who made this study possible.

\section{REFERENCES}

1. Rowbotham ES and Magill I. Anaesthetics in the plastic surgery of the face and jaws. Proc R Soc Med. 1921;14(Sect Anaesth):17-27.

2. Kovac AL. Controlling the hemodynamic response to laryngoscopy and endotracheal intubation. J ClinAnesth. 1996;8(1):63-79.

https://doi.org/10.1016/0952-8180(95)00147-6

3. Zwiebel WJ. Sonographic diagnosis of hepatic vascular disorders. Semin Ultrasound CT MRI. 1995;16(1):34-48.

https://doi.org/10.1016/0887-2171(95)90013-6

4. Stoelting RK. Blood pressure and heart rate changes during short-duration laryngoscopy for tracheal intubation: Influence of viscous or intravenous lidocaine. AnesthAnalg. 1978;57(2):197199.

https://doi.org/10.1213/00000539-197803000-00009

5. Kihara S, Brimacombe J, Yaguchi Y, Watanabe S, Taguchi N and Komatsuzaki T. Hemodynamic responses among three tracheal intubation devices in normotensive and hypertensive patients. AnesthAnalg. 2003;96(3):890-895.

https://doi.org/10.1213/01.ANE.0000048706.15720.C9 
6. Xue FS, Zhang GH, Sun HY, Li CW, Li P, Sun HT, et al. Blood pressure and heart rate changes during intubation: A comparison of direct laryngoscopy and a fibreoptic method. Anaesthesia. 2006;61(5):444-448.

https://doi.org/10.1111/j.1365-2044.2006.04584.x

7. Kerr ME, Rudy EB, Weber BB, Stone KS, Turner BS, Orndoff PA, et al. Effect of short-duration hyperventilation during endotracheal suctioning on intracranial pressure in severe headinjured adults. Nurs Res. 1997;46(4):195-201.

https://doi.org/10.1097/00006199-199707000-00003

8. Xue FS, Liao X, Liu KP, Liu Y, Xu YC, Yang QY, et al. The circulatory responses to tracheal intubation in children: A comparison of the oral and nasal routes. Anaesthesia. 2007;62(3):220-226.

https://doi.org/10.1111/j.1365-2044.2007.04939.x

9. Eilers $\mathrm{H}$ and Niemann $\mathrm{C}$. Clinically important drug interactions with intravenous anaesthetics in older patients. Drugs Aging. 2003;20(13):969-980.

https://doi.org/10.2165/00002512-200320130-00002

10. Fox EJ, Sklar GS, Hill CH, Villanueva $R$ and King BD. Complications related to the pressor response to endotracheal intubation. Anesthesiology. 1977;47(6):524-525.

https://doi.org/10.1097/00000542-197712000-00013

11. Donegan MF and Bedford RF. Intravenously administered lidocaine prevents intracranial hypertension during endotracheal suctioning. Anesthesiology. 1980;52(6):516-518.

https://doi.org/10.1097/00000542-198006000-00014

12. Tam S, Chung F and Campbell M. Intravenous lidocaine: Optimal time of injection before tracheal intubation. AnesthAnalg. 1987;66(10):1036-1038.

13. Moghaddam MJ, Barkhori A, Mirkheshti A, Hashemian M and Mohajerani SA. The effect of pre-emptive dexmedetomidine on the incidence of post-thoracotomy pain syndrome in patients undergoing coronary artery bypass grafting. Anesth Pain Med. 2016;6(3):e36344.

https://doi.org/10.5812/aapm.36344

14. Li Y, Wang B, Zhang LL, He SF, Hu XW, Wong GT, et al. Dexmedetomidine combined with general anesthesia provides similar intraoperative stress response reduction when compared with a combined general and epidural anesthetic technique. AnesthAnalg. 2016;122(4):1202-1210.

https://doi.org/10.1213/ANE.0000000000001165

15. Chi X, Liao $M$, Chen $X$, Zhao $Y$, Yang L, Luo A, et al. Dexmedetomidine attenuates myocardial injury in off-pump coronary artery bypass graft surgery. J CardiothoracVascAnesth . 2016;30(1):44-50.

https://doi.org/10.1053/j.jvca.2015.06.026

16. Wang SS, Zhang MZ, Sun Y, Wu C, Xu WY, Bai J, et al. The sedative effects and the attenuation of cardiovascular and arousal responses during anesthesia induction and intubation in pediatric patients: A randomized comparison between two different doses of preoperative intranasal dexmedetomidine. PaediatrAnaesth. 2014;24(3):275-281. https://doi.org/10.1111/pan.12284

17. Ghaus MS, Singh V, Kumar A, Wahal R, Bhatia VK and Agarwal J. A study of cardiovascular response during laryngoscopy and intubation and their attenuation by ultrashort acting b blocker esmolol. Indian J Anaesth. 2002;46(2):104.

18. Ebert TJ, Bernstein JS, Stowe DF, Roerig D and Kampine JP. Attenuation of hemodynamic responses to rapid sequence induction and intubation in healthy patients with a single bolus of esmolol. J ClinAnesth. 1990;2(4):243-252.

https://doi.org/10.1016/0952-8180(90)90104-b

19. Singh H, Vichitvejpaisal $P$, Gaines $G Y$ and White PF. Comparative effects of lidocaine, esmolol, and nitroglycerin in modifying the hemodynamic response to laryngoscopy and intubation. J ClinAnesth. 1995;7(1):5-8. https://doi.org/10.1016/0952-8180(94)00013-t

20. Wang L, Luo A and Wu X. Bolus administration of esmolol for preventing the haemodynamic response to tracheal intubation: A multicentre clinical study. Zhonghua Yi XueZaZhi. 1999;79(11):828-831.

21. Hussain AM and Sultan ST. Efficacy of fentanyl and esmolol in the prevention of haemodynamic response to laryngoscopy and endotracheal intubation. J Coll Physicians Surg Pak. 2005; 15(8):454-457.

22. Paris $\mathrm{A}$ and Tonner $\mathrm{PH}$. Dexmedetomidine in anaesthesia. CurrOpinAnaesthesiol. 2005;18(4):412-418. https://doi.org/10.1097/01.aco.0000174958.05383.d5

23. Miller DR, Martineau RJ, Wynands JE and Hill J. Bolus administration of esmolol for controlling the haemodynamic response to tracheal intubation: The Canadian multicentre trial. Can J Anaesth. 1991;38(7):849-858.

24. Anish Sharma NG, Shankaranarayana PP. Pre-medication with IV dexmedetomidine vs. IV clonidine in attenuating the pressor response during laryngoscopy and endotracheal intubation. Int J Biomed Res. 2014;5:465-7.

25. Fernandez-Galinski S, Bermejo S, Mansilla R, Pol $O$ and Puig MM. Comparative assessment of the effects of alfentanil, esmolol or clonidine when used as adjuvants during induction of general anaesthesia. Eur J Anaesthesiol. 2004;21(6):476-482. https://doi.org/10.1017/s0265021504006106

26. Srivastava VK, Agrawal S, Gautam SK, Ahmed M, Sharma $S$ and Kumar R. Comparative evaluation of esmolol and dexmedetomidine for attenuation of sympathomimetic response to laryngoscopy and intubation in neurosurgical patients. J AnaesthesiolClinPharmacol. 2015;31(2):186-190. https://doi.org/10.4103/0970-9185.155146

27. Dexmedetomidine Versus Esmolol to Attenuate the Hemodynamic Response to Laryngoscopy and Tracheal Intubation: A Randomized Double-blind Clinical Study; 2020.

28. Gogus N, Akan B, Serger N, Baydar M, Gogus N, Akan B, et al. The comparison of the effects of dexmedetomidine, fentanyl and esmolol on prevention of hemodynamic response to intubation. Rev Bras Anestesiol. 2014;64(5):314-319. https://doi.org/10.1016/j.bjan.2013.10.010

\footnotetext{
Authors Contribution:

VRH-Concept and design of the study, prepared first draft of manuscript; VC-Interpreted the results, reviewed the literature, and manuscript preparation; and RN-Concept, coordination, statistical analysis and interpretation, preparation of manuscript, and revision of the manuscript

Work attributed to:

Sri ManakulaVinayagar Medical College and Hospital, Pondicherry - 605 107, India

Orcid ID:

Dr. Vigneshwaran Chandramohan- (i) https://orcid.org/0000-0002-1792-5590

Dr. Ramya Natarajan- (iD https://orcid.org/0000-0003-4236-1026

Dr. Vishwanath R Hiremath- (i) https://orcid.org/0000-0003-1926-3129

Source of Support: Nil, Conflict of Interest: None declared.
} 